Levy, E., Rippon, J. E. \& Wilutams, R. E. O. (1953). J. gen. Microbiol. 9, 97-100.

\title{
Relation of Bacteriophage Pattern to some Biological Properties of Staphylococci
}

\author{
BY E. LEVY \\ Bacteriology Department, St George's Hospital Medical School, London \\ JOAN E. RIPPON AND R. E. O. WILLIAMS \\ Staphylococcal Reference Laboratory, Public Health Laboratory Service, \\ Colindale, London, N.W. 9
}

\begin{abstract}
SUMMARY: Representative coagulase-positive staphylococci that had been examined for their production of diffusible antigens, $\alpha$ - and $\beta$-haemolysins, fibrinolysin and pigment, were typed by bacteriophage. Among strains from human sources there was no significant association between the phage group and the other properties. Strains of staphylococci obtained from animals seemed, however, to form a different biological group from those from human beings.
\end{abstract}

Although it is known that certain phage-types of staphylococci are particularly common as the cause of some staphylococcal diseases, such as food poisoning (Williams, Rippon \& Dowsett, 1953), there is no similar information on the association of these types with any other physiological property except penicillinase production, although Smith (1948) reported differences between human and animal strains. We therefore determined the phage types of a series of staphylococci whose biological properties had previously been studied (Elek \& Levy, $1950 a, b)$.

\section{METHODS}

The phage typing was carried out by the methods already described (Williams \& Rippon, 1952) and the strains were classified on the basis of the pattern of lysis by the phages into three groups (Williams \& Rippon, 1952, Williams, Rippon \& Dowsett, 1953) known as I (the '52 group'), II (the ' $3 \mathrm{~A}$ group') and III (the '6/47 group'). Strains that were lysed by some of the phages, but which could not be fitted into this classification were called 'unclassifiable'. Some of the strains proved resistant to all phages used at their routine test dilution, but sensitive to undiluted phages; these are called 'partially typable'. Others were resistant even to the undiluted phages and called 'completely untypable'.

The techniques employed for the determination of diffusible antigens, $\alpha$ - and $\beta$-haemolysin production and pigment formation, together with details of the origins of the strains have been fully described in previous publications (Elek \& Levy, $1950 a, b$ ).

For the determination of fibrinolysin, double strength basal medium as described in these papers was employed and mixed with equal quantities of human plasma. The poured plates were heated at $56^{\circ}$ until turbid, to precipitate fibrin. After inoculation they were incubated in an atmosphere of $30 \%$ carbon dioxide and $70 \%$ air at $37^{\circ}$ for $24 \mathrm{hr}$. All strains were first tested by 
spot inoculation on to these plates. A circular area of clearing wider than the diameter of the growth was regarded as indicating fibrinolysin production. Strains negative by this test were recorded as fibrinolysin-negative. The positive reactions were confirmed on similar plates incorporating strips of filter-paper soaked in Burroughs Wellcome Refined Staphylococcal Globulins (1250 units $\alpha$-antitoxin/ml.). Streak inoculations were made at right angles to the strips, up to six organisms being tested on one plate. The plates were then treated as described for the spot inoculation procedure. This routine was adopted to see whether any differentiation of fibrinolysins analogous to that of the haemolysins would be possible. This did not prove to be the case, and with all the strains found fibrinolysin-positive by the spot method, the zones of clearing in the streak method were inhibited by the antiserum.

\section{RESULTS}

Of the 254 strains tested, fifty were derived from animal sources (Table 1); with one exception the animal strains were in phage group III, or were unclassifiable or untypable. No fewer than sixteen of the twenty-five strains that were not lysed even by the undiluted phages were from animals.

Table 1. Phage group of strains from human and animal sources

$\begin{array}{lccc}\text { Phage group } & \begin{array}{c}\text { No. of strains } \\ \text { tested }\end{array} & \begin{array}{c}\text { Percentage of strains } \\ \text { Human sources } \\ \text { Animal sources }\end{array} \\ \text { I } & 85 & 98 \cdot 8 & 1 \cdot 2 \\ \text { II } & 26 & 100 \cdot 0 & 0 \\ \text { III } & 68 & 75 \cdot 0 & 25 \cdot 0 \\ \text { Unclassifiable } & 12 & 66 \cdot 7 & 33 \cdot 3 \\ \text { Partially typable } & 38 & 68 \cdot 4 & 31 \cdot 6 \\ \text { Completely untypable } & 25 & \mathbf{3 6} \cdot 0 & 64 \cdot 0 \\ \quad \text { Total } & 254 & 80 \cdot 3 & 19 \cdot 7\end{array}$

Table 2. Pigment production by staphylococci of different phage groups

\begin{tabular}{|c|c|c|c|c|c|c|}
\hline \multirow[b]{3}{*}{ Phage group } & \multirow{3}{*}{$\begin{array}{l}\text { No. of } \\
\text { strains }\end{array}$} & \multicolumn{5}{|c|}{ Percentage with colonies } \\
\hline & & \multirow[b]{2}{*}{ White } & \multirow[b]{2}{*}{ Off white } & \multicolumn{3}{|c|}{ Golden } \\
\hline & & & & 1 & 2 & $\mathbf{3}^{*}$ \\
\hline I & 85 & $\mathbf{3 \cdot 5}$ & o & $21 \cdot 2$ & $42 \cdot 4$ & $32 \cdot 9$ \\
\hline II & $\mathbf{2 6}$ & $\mathbf{3} \cdot \mathbf{8}$ & $15 \cdot 4$ & $19 \cdot 2$ & $19 \cdot 2$ & $42 \cdot 4$ \\
\hline III & 68 & $14 \cdot 7$ & $11 \cdot 7$ & $25 \cdot 0$ & 32.4 & $16 \cdot 2$ \\
\hline Unclassifiable & 12 & $\mathbf{0}$ & $16 \cdot 7$ & $\mathbf{3 3} \cdot \mathbf{3}$ & $\mathbf{2 5} \cdot 0$ & $25 \cdot 0$ \\
\hline $\begin{array}{l}\text { Partially } \\
\text { typable }\end{array}$ & 38 & $\mathbf{0}$ & $10 \cdot 5$ & $26 \cdot 3$ & $42 \cdot 2$ & $21 \cdot 0$ \\
\hline $\begin{array}{c}\text { Completely } \\
\text { untypable }\end{array}$ & 25 & $12 \cdot 0$ & $12 \cdot 0$ & $\mathbf{4 0 \cdot 0}$ & $28 \cdot 0$ & $8 \cdot 0$ \\
\hline Total & 254 & $6 \cdot 7$ & $\mathbf{8 \cdot 3}$ & $\mathbf{2 5} \cdot 2$ & $35 \cdot 0$ & $\mathbf{2 4} \cdot \mathbf{8}$ \\
\hline
\end{tabular}

Strains of groups I and II, which were almost exclusively from human sources, did not differ in any of the characteristics studied; and none of the groups differed in their mean number of flocculation lines (Tables 2 and 3). 
Group III and the completely untypable group contained a greater proportion than the others of strains that were poorly pigmented, or produced $\beta$-haemolysin, and they also contained a smaller proportion than the others of fibrinolysin-producing strains. The two last characteristics were also noted in the unclassifiable and the partially typable groups. It seems that these differences could be explained by the fact that they are characteristic of animal strains, which were common in these groups (see Table 4).

Table 3. Production of flocculation lines, haemolysin, and fibrinolysin by staphylococci of different phage groups

\begin{tabular}{|c|c|c|c|c|c|c|c|}
\hline \multirow[b]{3}{*}{ Phage group } & \multicolumn{2}{|c|}{ Flocculation lines } & \multicolumn{3}{|c|}{ Haemolysins } & \multicolumn{2}{|c|}{ Fibrinolysin } \\
\hline & \multirow{2}{*}{$\begin{array}{l}\text { No. of } \\
\text { strains } \\
\text { tested }\end{array}$} & \multirow{2}{*}{$\begin{array}{c}\text { Mean } \\
\text { no. } \\
\text { lines }\end{array}$} & \multirow{2}{*}{$\begin{array}{l}\text { No. of } \\
\text { strains } \\
\text { tested }\end{array}$} & \multicolumn{2}{|c|}{$\begin{array}{c}\% \\
\text { producing }\end{array}$} & \multirow{2}{*}{$\begin{array}{l}\text { No. of } \\
\text { strains } \\
\text { tested }\end{array}$} & \multirow{2}{*}{$\begin{array}{c}\% \\
\text { positive }\end{array}$} \\
\hline & & & & $\alpha$ & $\beta$ & & \\
\hline $\mathbf{I}$ & 85 & $6 \cdot 3$ & 85 & $94 \cdot 2$ & $7 \cdot 1$ & 82 & $81 \cdot 7$ \\
\hline II & 26 & $6 \cdot 5$ & 26 & $96 \cdot 2$ & $7 \cdot 7$ & 25 & $88 \cdot 0$ \\
\hline III & 68 & $5 \cdot 9$ & 68 & $91 \cdot 2$ & $32 \cdot 4$ & 65 & $75 \cdot 5$ \\
\hline Unclassifiable & 12 & $5 \cdot 8$ & 12 & $91 \cdot 7$ & $50 \cdot 0$ & 12 & $50 \cdot 0$ \\
\hline $\begin{array}{l}\text { Partially } \\
\text { typable }\end{array}$ & $\mathbf{3 8}$ & $6 \cdot 1$ & $\mathbf{3 8}$ & $92 \cdot 1$ & $\mathbf{3 6} \cdot 8$ & $\mathbf{3 6}$ & $66 \cdot 7$ \\
\hline $\begin{array}{l}\text { Completely } \\
\text { untypable }\end{array}$ & 25 & $5 \cdot \mathbf{3}$ & 25 & $88 \cdot 0$ & $64 \cdot 0$ & 24 & $62 \cdot 5$ \\
\hline Total & 254 & $6 \cdot 02$ & 254 & $92 \cdot 5$ & $26 \cdot 0$ & 244 & $75 \cdot 0$ \\
\hline
\end{tabular}

Table 4. Comparison of staphylococci from human and animal sources

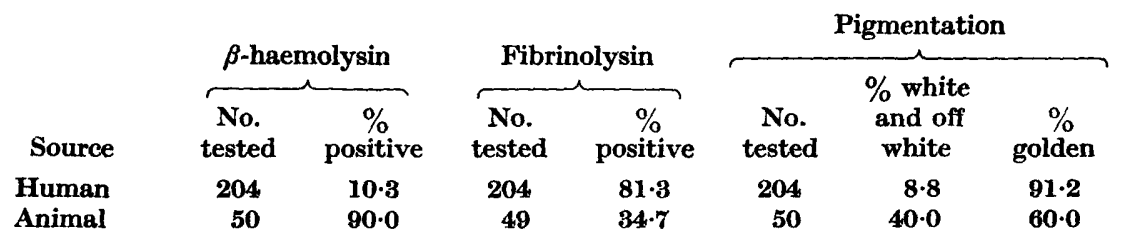

The fact that the animal strains are less often typable than the human is not surprising, since the phages were collected principally for the identification of human strains. Smith (1948) also showed that strains from cows frequently had the phage pattern $42 \mathrm{D}$, which is relatively rare among human strains, and that strains from sheep were quite untypable with the set of phages used for typing human strains, although susceptible to other phages. These facts and the other known differences in the metabolic activities of human and animal strains, some of which we have confirmed, suggest that the strains from animals form a different biological group from those derived from human sources.

The substance of this paper formed part of a thesis submitted by $\mathbf{E}$. Levy for the Ph.D. degree in the University of London, July 1952. 


\section{REFERENCES}

EuEK, S. D. \& LEVY, E. (1950a). Diffusible antigens in staphylococcal cultures. Brit. J. exp. Path. 31, 358.

ELEK, S. D. \& LEVY, E. (1950b). Distribution of haemolysins in pathogenic and non-pathogenic staphylococci. J. Path. Bact. 62, 541.

Smiтr, H. W. (1948). The typing of staphylococci of animal origin by the bacteriophage method. J. comp. Path. 58, 179.

Williams, R. E. O. \& Rippon, J. E. (1952). Bacteriophage typing of Staphylococcus aureus. J. Hyg., Camb. 50, 320.

Williams, R. E. O., Rippon, J. E. \& Dowsett, L. M. (1953). Bacteriophage typing of strains of Staphylococcus aureus from various sources. Lancet, i, 510.

(Received 12 February 1953) 